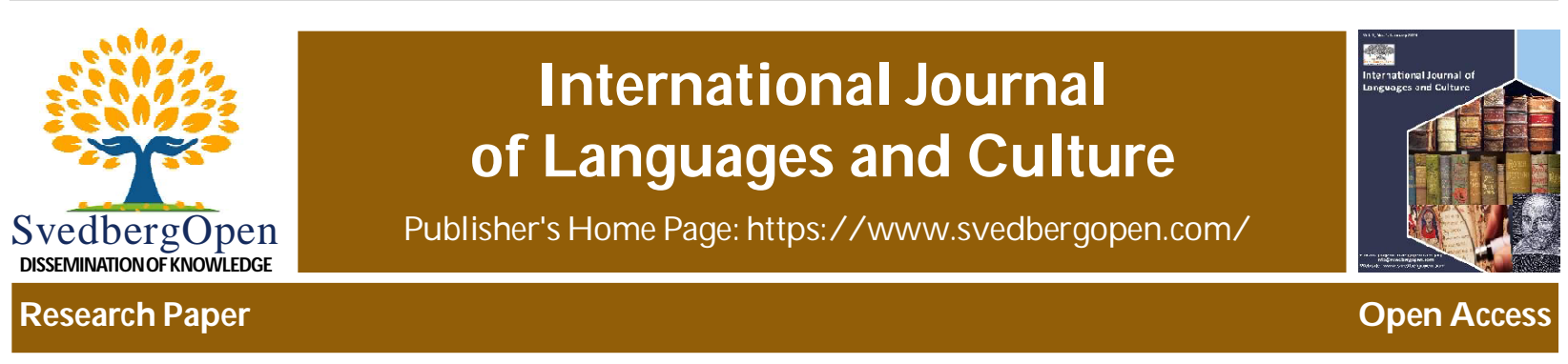

\title{
Pluralism Education in Novels Dear Angel Izrail
}

Latifah Maurinta Wigati ${ }^{*}$

${ }^{1}$ Indonesian Education University, Indonesia. E-mail: 1.maurinta.wigati@gmail.com

\begin{tabular}{|c|c|}
\hline Article Info & $\begin{array}{l}\text { Abstract } \\
\text { Indonesia has a diversity of ethnicities and religions. Coexistence is a necessity in this } \\
\text { country. In order for multicultural and multireligious societies to coexist, a spirit of pluralism }\end{array}$ \\
\hline $\begin{array}{l}\text { Volume 1, Issue 3, September } 2021 \\
\text { Received : } 31 \text { January } 2021 \\
\text { Accepted : } 17 \text { July } 2021 \\
\text { Published : } 05 \text { September } 2021 \\
\text { doi: 10.51483/IJLC.1.3.2021.18-24 }\end{array}$ & $\begin{array}{l}\text { channel pluralism values through prose. Dear Malangel Izrail's novel teaches pluralism } \\
\text { with the diversity and ability of the characters to be tolerant. This novel can be a reference } \\
\text { for plural character education for the younger generation. This study is qualitative in nature } \\
\text { and the data is collected using documentation techniques. Indonesia has a diversity of } \\
\text { ethnicities and religions. Coexistence is a necessity in this country. In order for multicultural } \\
\text { and multireligious societies to coexist, a spirit of pluralism is needed. The spirit of pluralism } \\
\text { can be taught through literature. This study aims to channel pluralism values through the } \\
\text { process. Dear Malangel Izrail's novel teaches pluralism with the diversity and ability of the } \\
\text { characters to be tolerant. This novel can be a reference for plural character education for the } \\
\text { younger generation. This study is qualitative in nature and the data is collected using } \\
\text { documentation techniques. } \\
\text { Keywords: Pluralism, Education, Indonesia, Literature, Multicultural, Multireligious } \\
\text { the CC BY license (https://creativecommons.org/licenses/by/4.0/), which permits unrestricted } \\
\text { use, distribution, and reproduction in any medium, provided you give appropriate credit to the original } \\
\text { author(s) and the source, provide a link to the Creative Commons license, and indicate if changes were made. }\end{array}$ \\
\hline
\end{tabular}

\section{Introduction}

The complexity of pluralism is an endless issue to discuss. Indonesia is a country that has rich ethnicity, culture and religion. There are six officially recognized religions in the country: Islam, Hinduism, Buddhism, Catholicism, Protestantism and Confucianism. Referring to the 2010 BPS census, Indonesia has 1,340 ethnic groups.

If traced from its history, Indonesia was founded by people of different ethnicities and religions with the same desire. They were bound by the same fate and hope to free themselves from the shackles of colonialism and form an independent state. On this basis, the Indonesian state has been established until now. Indonesia has Pancasila with its five principles which guarantee the right to embrace a religion according to their respective beliefs and every citizen, regardless of religion, has the same rights and obligations. The freedom to embrace religion according to the choice of the heart is contained in the first principle of Pancasila, namely God Almighty and Article 28 I Paragraph 1 of the 1945 Constitution.

Although the foundation of the state has guaranteed justice for every citizen regardless of race and religion, the complexity of pluralism cannot be avoided. The spirit of pluralism will only be created from an open mind and a heart that

\footnotetext{
* Corresponding author: Latifah Maurinta Wigati, Indonesian Education University, Indonesia. E-mail: 1.maurinta.wigati@gmail.com
} 
is willing to accept differences. Until now, there is still friction in the name of differences. There are still many certain groups who are reluctant to accept differences and live side by side.

Aan Anshori, a lecturer in Pancasila and Religion at Ciputra University as well as an activist for Gusdurian and the Anti-Discrimination Islamic Network said in one of his seminars that one form of preventing pluralism is Law no. 1 of 1974 concerning marriage. This marriage law is implicitly against interfaith marriage. This minimizes the chances of assimilation between people of different religions with one another.

Islam is the majority religion in Indonesia. Furthermore, in his seminar, Anshori divides the three groups of Muslims as:

1. Conservative Muslims (this group closes itself to associating with followers of other religions, does not want to enter houses of worship of other religions, is afraid of the attributes/symbols of other religions, and tends not to care about the problems faced by other religions).

2. Moderate Islam (a group that is willing to accept visits from members of other religions but does not want to make return visits, is not afraid of symbols of other religions, and does not pay attention to problems faced by other religions).

3. Progressive Islam (a group that is open to other religions, wants to visit them on holidays of other religions, wants to enter the worship of other religions, is not afraid of other religious symbols, and cares about the problems of other religions).

The classification and blocking of pluralism has made the minority's position unsafe. The minority is the party that is marginalized, defeated, discriminated against, and unprotected. The complexities of pluralism that occur and deserve attention include:

1. The election of the Student Council Chairperson at SMAN 6 Depok was repeated only because those elected were non-Muslims (Suara, 2020).

2. Portrait of students from minority groups who tell stories of their suffering being bullied because they are different (Aan Anshori's story on his personal website).

3. A resident is refused to live in Dusun Karet, Yogyakarta, simply because he is not Muslim (Detik, 2019).

4. Removal of the cross from the grave (Kompas.com, 2018).

5. Bomb explosion that destroyed three churches in Surabaya (BBC, 2018).

Two of the above cases came from an educational setting. In fact, the terrorism case in the Surabaya church has involved young children. This shows the need to strengthen pluralism through education.

Adrian Beard in his book said that books can influence readers in their actions. Books cannot directly prevent crime, but the presence of a text/book can influence the reader's mind. Influence is what makes them have a choice in taking action. In a text, especially the text of the story, the value and message the author wants to convey is stored. There are explicit messages (messages that are conveyed directly as in folk tales or children's fairy tales), and implicit messages that readers must interpret and discover.

Literary works have a major influence in shaping children's character and personality. In some developed countries, literary books have become mandatory reading for students. This policy has also been implemented by several private schools in Indonesia. Students are required to read literary books to avoid racism.

The younger generation is a generation that does not like being lectured or indoctrinated by force. Character education values will be easier to digest through other content such as shows or stories. Literary work is a middle way to introduce the value of pluralism to the younger generation.

Dear Malangel Izrail novel was chosen because its story is relevant to two major events that are the embodiment of diversity friction. The two incidents were the bombing of three churches in Surabaya and the shooting of a mosque in New Zealand. Apart from being a novel, this story also has another product, namely a film script. The script for the film Dear Malangel Izrail once led the author to be selected as the top 70 Masterclass Looking for Writers held by Rich Indonesia with Garin Nugroho and Nia Dinata. Previously, this novel was researched by Khatimah (2019) in her thesis with a psychoanalytic approach.

In this study, research questions can be drawn in the form of: 
1. What is the picture of pluralism in Dear Malangel Izrail's novel?

2. How is the relevance of the complexity of pluralism in Dear Angel Izrail's novel to the current situation?

This study aims to:

1. Describe the picture of pluralism contained in the novel Dear Mal Angel Izrail.

2. Describe the relevance of the pluralism complexity in Dear Malangel Izrail's novel with real life situations.

Theoretically, this study is useful for adding references to studies in the field of pluralism education in literary works. The practical benefit is an effort to instill the value of pluralism in society for the creation of a peaceful life.

Sutikno (2018) has conducted a similar research. In his journal, he researched plurali sme in Okky Madasari's Maryam novel. Saroni, in his thesis, examines the concept of pluralism in the Novel Rumah Di Seribu Ombak. Mar'atus Sholihah examines pluralism in the novel Five Towers by Ahmad Fuadi.

This study is a descriptive qualitative study. The data is taken by reading technique with the method of studying and understanding it. The technique is in the form of word, sentence, and narrative analysis. This study is in the form of literature review with the source in the form of books.

\section{Theoritical Review}

Didactic literature is limited to literary works designed u n tuk describes a branch il mu, both theoretical and practical, or perhaps also to establish a theme or doctrine of moral, religious, or philosophical in the form of fiction, imaginative, persuasive, d an impressive (Abrams, 1981). Sumiyadi in his writings, Education Literature and Literature Education, calls didactic literature as educational literature. Literary works are aesthetic in nature and contain expressions of the writer's thoughts. However, not all literary works are in accordance with moral and educational values. Didactic literature is rarely practiced by writers unless they work on didactic literature or orders from certain parties. This type of literary work is fixated on the values and knowledge to be conveyed.

Examples of didactic literary works can be found in the novels by Habiburahman El Shirazy, Helvy Tiana Rossa, and Asma Nadia. They insert a religious message through the novel. Didactic literature does not only focus on moral and religious values. This type of literature can convey other sciences in his work such as sociology, history, health, philosophy, psychology, anthropology, physics, chemistry, etc.

There is also another type of literary work that is almost similar to didactic literature, namely propaganda literature. Propaganda literature is equivalent (Abrams, 1981). Propaganda literature to influence the reader's mind to be motivated to take action based on moral and political values conveyed in literary works.

Not all didactic literature can be used for teaching in schools. There are times when a didactic literary work was created and owned by a certain group, ethnicity and religion. A filter is needed so that a didactic literary work can be taught in schools. The purpose of introducing didactic literary works to students is so that students can enjoy, appreciate, and absorb the messages they want to convey in the didactic literary work.

The purpose of introducing didactic literature to students:

1. Character building

2. Widening knowledge

3. Improve language skills

4. Shaping student personality

Another element that is no less important when choosing didactic literary works for students is the aesthetic aspect. The value of beauty and literature is the difference between literary works and other writings. Apart from the four objectives above, students are expected to have a sense of taste and creativity after reading didactic literature. It is possible that students will be called to make a literary work after enjoying didactic literary work.

Literary analysis has innovated over time. The teacher does not only ask about the intrinsic elements of literary works in the form of themes, settings, plot, characters, and messages. Questions to students after enjoying and appreciating literature can be expanded. Teachers can ask students thoughts, feelings, and views after enjoying didactic literary works. This is relevant to the development of contemporary literary theories that are not as rigid as structural theory. 
Pluralism is part of social science. This understanding can be interpreted as the ability of groups with differences to respect, tolerate, and interact without conflict on behalf of differences. Pluralism can be achieved when different groups respect each other's differences and acknowledge that they exist. Pluralism emphasizes the acceptance of differences without taking issue with them or triggering confrontation just because they are different.

According to KBBI, pluralism is a condition of a plural society (concerned in its social and political system), a variety of different cultures in a society. Pluralism is an attempt to build theological normative awareness and social awareness. (Mohammad Shofan). Syamsul Maa'arif defines pluralism as an attitude of mutual understanding and respect for differences in order to achieve harmony between religious communities.

Attitudes that reflect pluralism include:

1. Tolerance (coexistence in differences)

2. Able to accept other people with different views of life

3. Mutual respect

4. Putting humans in an equal position

\section{Discussion}

Novel title: Dear Angel Izrail

Author: Maurinta

Publisher: Benito Publisher

Publication year: 2019

Number of pages: 154

Synopsis

Jose Gabriel Calvin, a young young man of Chinese descent who lives with his father, Calvin's father. He is friendly with Andrio, a boy of Sundanese-English descent who is Muslim, Livio, a cross-blooded Ambonese-Dutch Catholic, and Hito, a boy of mixed Javanese-Japanese blood who is a Buddhist. They are always together. To their respective places of worship together. Unfortunately, all three of Jose's friends were killed in a terrorist attack that hit the mosque, church and monastery. Jose was devastated. He was sad because the Angel Izrail took his friends. Calvin's father helped Jose to be strong and endure this sadness. In the end, Jose was able to rise again from sadness. He even won the class, published a musical novel, and became a tolerance activist.

\section{A. Pluralism}

The value of pluralism in the novel Dear Malangel Izrail is proven by the following quotations:

Quote 1:

Since childhood, the four of them are friends. Andrio is a Sundanese child of English descent. Livio is of Ambon-Dutch blood. Hito's father is Javanese and his mother is Japanese. Jose is a Chinese leader. Even though they are different, they love each other. Differences are beautiful, Calvin's father taught Jose.

The quote shows that Jose and his friends recognized the meaning of diversity from an early age. They get a message from their parents that differences can be something beautiful. Regardless of ethnicity, they love and love each other.

Quote 2:

As soon as the door opened, Jose glared at once. Andrio, Livio, and Hito stood at the door of the room. The three of them seemed to laugh with satisfaction.

"What are you doing to wake me up? I'm still sleepy you know!” he protested.

"Yeee... instead of thank you it actually protested! It's already dawn!” Livio replied.

Jose's eyes widened. He hurriedly took ablution. Meanwhile, his three friends laughed with amusement when he was in such a hurry.

In the above quote, it appears that Jose's three friends woke him up for the Fajr prayer. Among the three of them, there are different religions. Livio and Hito want to remind Jose to worship according to their religion even though they are not 
Muslims. This reflects a form of high tolerance for religious differences. What Livio and Hito did shows that they understood the religious rites Jose had to do and reminded Jose to do that.

Quote 3:

"Everyone is equal in God's eyes. It cannot be distinguished only because of ethnicity and religion."

"Everyone is the same, honey. Anyway, Jose can't be different from his friends. Okay?"

The parental advice to their children is illustrated in the above quote. Parents instill the value of pluralism through speech. Parents remind children from childhood not to differentiate between friends just because of differences in ethnicity and religion.

Quote 4:

"Sorry if I bothered you. Adi has bullied his friend. He threw racist insults at Andrio," said Calvin's father.

Two foreign words slid into Jose's head. He doesn't know what bully and racism mean. The boy's brain was spinning fast, trying to make sense of the two foreign words he had just heard. Even though he doesn't know the meaning, Jose feels that the two words mean evil things.

This quote occurs when Calvin's father calls Adi's parents to school. Adi is described as a racist bad boy. He bullied Andrio on behalf of ethnic differences. Even though he didn't understand the meaning of the two words, Jose's subconscious warned him that the words 'bully' and 'racist' meant nothing good. Her brain had formed the convention that bullying and differentiating people just because of racial differences is not good. Since he was a child, Jose's instincts were tempered to say no to racism and bullying.

Quote 5:

"Yeee, can't I come with you? I took Sharon to church earlier. Let's go to your house too," he said.

Jose is even more surprised. He just found out that Silvi wanted to accompany his friend to church.

"I often escort him. Abis, I'm sorry. Just hanging around is okay," excused the little girl.

The four boys admired Silvi. Despite having different religions, Silvi wants to take Sharon to worship. The little girl was worthy of them going out together this morning. They also said goodbye to Calvin's father. The five of them walked hand in hand through the complex.

Sunday morning, it's time for Jose and Andrio to accompany Livio and Hito. Livio to the church and Hito to the monastery. It goes on every week, all year long. On Friday afternoon, it was Livio and Hito's turn to accompany Andrio and Jose.

The above quote shows Jose and his friends open to other religions. Their tolerance is so high. They accompany each other to places of worship. The five children were not afraid when they had to visit places of worship of other religions. There is no prejudice and concern that they will be told to convert to another religion if they visit a house of worship that does not belong to their religion. Things like this need to be introduced to children from an early age. Not only being introduced to the places of worship of the religion they embrace, children also need to be invited to get to know places of worship of other religions.

Quote 6:

Church, mosque and monastery stand side by side. People from the three places of worship greet each other as they pass by. The mosque priest was seen chatting friendly with priests and monks on the church terrace. Calvin's father greets the people there, smiling warmly after opening the car window. They greeted him back.

The above quote describes a harmonious portrait of the three religions. Churches, mosques and monasteries stand side by side without conflict. Even the three religious leaders looked familiar. People of different religions greet each other with other religious leaders. This simple form of tolerance can erode inherent fanaticism and dissolve prejudice.

Quote 7:

Calvin's father's face continued to show. It was his father who taught Jose the meaning of difference and tolerance. When we are tolerant, harmony will manifest. Harmony does not equalize differences, but makes all differences go hand in hand in one path. Harmony makes peace, makes people no longer hate each other just because they are different.

In this novel, parents give a big influence for children to recognize tolerance. The life lessons from Calvin's father have always remained on Jose's mind. Tirelessly, Calvin's father taught him the meaning of difference. Tolerance is not 
equalizing differences or forcing differences to unite. However, tolerance means making all differences go hand in hand. If a group of people can tolerate, they will live in peace. No more hatred in the name of difference.

Quote 8:

His gaze was fixed on the church congregation and the Buddhists shaking each other. He joined in and greeted them politely.

Jose is Muslim. However, he is friendly and open with people of other religions. He wanted to greet them. This simple form of interaction shows tolerance and openness to people of different religions.

Quote 9:

"We have to pray for them, honey. Even though they are different from us."

Jose started chanting a prayer.

In the above quote, Calvin's father taught Jose to pray for his friends of different religions. Jose also prayed for them in the Islamic way. This shows that prayer, regardless of religion, can be given to anyone. Prayer does not have to be used only for people of faith. A person can pray for people of different religions according to their prayer rites. Regarding whether this prayer is accepted or not is God's prerogative. The point underlined is the willingness of people of one religion to pray for people of different religions. Not a prayer for someone to embrace their religion, but a sincere prayer for someone who has passed away. This kind of awareness belongs only to open-minded and big-minded people.

Quote 10:

"But..." Jose pointed at his chest. "Why does it hurt here? When that grandmother shouted 'Chinese' to Jose's face?" "Silvi, Papa's bidadarinya, you have to be good, yes, with other people who are different from you. Different opinions, different ethnicities, different religions."

Why, yes, do adults find it difficult to accept differences? Though different, right, a gift. Beda is beautiful. If you always want the same, the world will not be fun.

"Father, were Andrio, Livio, and Hito taken by God because they were different?"

"Evil! Why are they taken just because they are different?"

Quote 11:

Dear Angel Izrail,

I'm disappointed with adults. Complicated, like to fight, and don't like different things. I just found out, it turns out that some adults like to separate small children from their friends just because they are different.

What's wrong, huh? Why are different things wrong? Why do adults hate just because they are different?

The two quotes are a series of scenes where Jose experiences racist treatment from an old woman in a wheelchair. Although he still does not fully understand the insults directed at him, Jose is able to feel hurt at the racist insults. He was angry because his friends were killed just because of differences. Saved disappointment in the anti-difference group. Jose really appreciates differences. Children with pure hearts are taught the meaning of tolerance more easily than adults. They do not choose friends just because of ethnic and religious differences.

Quote 12:

The people who took their best friend did not understand the beauty of the difference. If they understood, they shouldn't have taken Andrio, Livio, and Hito. They are also emotional and easily provoked just because they are different. Jose is sad to remember it. Jose hopes that they will patiently face differences and realize that differences should not be separated, but united with love.

“Don't build a dividing wall, but build a bridge." That's Opa Effendi's message.

The above quotation shows that differences can be reconciled with love. People of different religions should not segregate each other. It is through these differences that they can actually unite. Differences can be dealt with with patience and awareness. Realized that they were different. They recognize differences and are willing to respect each other.

\section{B. Relevance to the situation}

Dear Mal Angel Izrail's novel is based on two bloody incidents based on hatred for differences. The first incident was the bombing of three churches in Surbaya in May 2018. The second incident was the shooting of a mosque in Christchurch, 
New Zealand in March 2019. The two incidents add to the long list of acts of terrorism in the name of religious differences.

The narrative in this novel is in accordance with the conditions that occur. It is not only about terrorism, but also about tolerance in the environment of children. In several scenes, Jose and his three friends accompany each other to a place of worship. This practice was exemplified by Astuti Sya'ban, the author of the novel Asa Malangel Mungilku. Every few months, he invites the children to visit mosques, churches, monasteries, temples and temples to introduce them to houses of worship of other religions. As stated by Astuti in the seminar "Chinese Gossip, Yuk" held by Rumah Bhinekka every Monday night, suspicions arose from several parties regarding this agenda. The suspicion that children will be indoctrinated to convert. This was broken because children were not brainwashed into converting religions, but were invited to recognize diversity.

Another relevance is the position of the house of worship. Places of worship that stand side by side are exemplified by the Istiqlal Mosque in Jakarta which is adjacent to the Cathedral Church. These two houses of worship can coexist without conflict and friction. Portraits of tolerance are shown at Christmas and Eid. There are times when church congregations and mosque congregation members share a parking space during holidays. The church will postpone the Mass schedule if Eid al-Fitr falls on a Sunday.

The third form of conformity is a matter of selecting class leaders. At the beginning of this novel, it is told that Jose's class held an election for class president. Prospective class leaders include Andrio, Jose, and Adi. Andrio was elected as class president. Adi doesn't like his class led by Andrio. According to him, Andrio is a foreigner. This situation is similar to the moment when the student council president was elected at SMAN 6 Depok. What great danger is that in the educational environment the seeds of racism and fanaticism have grown. That is why it is important to instill the value of pluralism from an early age.

\section{Conclusion}

Dear Mal Angel Izrail's novel provides a didactic value about pluralism. The story in the novel is based on two terrorism incidents. It is important to instill the value of pluralism from an early age so that children are not exposed to sentiments in the name of religion and ethnicity.

\section{References}

Abrams, Meyer Howard. (1981). A Glossary of Literary Terms. Holt, Rinehart and Winston.

Beard, Adrian. (2001). Texts and Context: An Introduction to Literature and Language Study. Routledge: London.

Khatimah, Mira. (2019). Psychological Disorders of the Main Character of the Novel Dear Angel Izrail by Maurinta. Essay. STKIP Banjarmasin.

Maurinta. (2019). Dear Angel Izrail. Benito Publisher: Jakarta.

Sutikno. (2018). Pluralism in the Novel Maryam by Okky Madasari. Journal of Literate Syntax, 3.

Sholihah, Mar'atus. (2017). Pluralism in the Novel Negeri Lima Menara by Ahmad Fuadi: A Semiotic Approach. Essay, Accessed at http://fib.unej.ac.id/id/pluralisme-novel-negeri-5-menara-karya-ahmad-fuadi-suatu-pendekatsemiotika/ accessed on 28 November 2020 .

Sahroni. (2015). The Value of Pluralism in the Novel Rumah di Seribu Ombak: Content Analysis. Thesis, UIN Sunan Kalijaga. Accessed at http://digilib.uin-suka.ac.id/15583/.

Sumiyadi. (2010). Literature Education and Literature Education. Jurdik Satrasia FPBS UPI. 2010. Accessed at http:// file.upi.edu/Dirirect/FPBS/JUR._PEND._BHS._DAN_SASTRA_INDONESIA/196603201991031-SUMIYADI/ SUMIYADI/SASTRA_PENDIDIKAN_DAN_PENDIDIKAN_SASTRA.pdf. Accessed on November 28, 2020_SASTRA.pdf

Anshori, Aan. (2020). Suffering in Religion Class. Accessed at www.aananshori.web.id >2020/10> suffering-in-religionclasses accessed on November 28, 2020.

Cite this article as: Latifah Maurinta Wigati (2021). Pluralism Education in N ovels Dear Angel Izrail. International J ournal of Languages and Culture 1(3), 18-24. doi:10.51483/ IJLC.1.3.2021.18-24. 